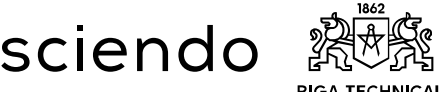 \\ RIGA TECHNICAL
UNIVERSITY
}

\section{TRAINING TRANSFER: A MODERATOR OF ENTREPRENEURIAL PERFORMANCE DETERMINANTS}

\author{
Kabiru Ishola GENTY \\ Lagos State University, Ojo Lagos, Nigeria \\ Corresponding author's e-mail: ishola.genty@lasu.edu.ng
}

\begin{abstract}
The present study examines the moderating effect of training transfer on the determinants of entrepreneurial performance among owners of micro, small and medium enterprises (MSMEs) in Lagos State, Nigeria. The study adopts a quantitative approach using a cross-sectional descriptive survey while Cochran (1977) formula for sample size determination is used to calculate the sample size. Structural Equation Modelling (SEM) approach and Multi-Group Analysis are applied to test the stated research hypothesis. Prior to full use of the model, the researcher ensures that the model meets the acceptable goodness-offit indices: $X^{2}(\mathrm{CMIN})=387.238(\mathrm{DF}=196)$, Relative $X^{2}(\mathrm{CMIN} / \mathrm{DF})=1.976$, AGFI $=0.870$, GFI $=0.899$, CFI $=0.939, \mathrm{IFI}=0.939, \mathrm{TLI}=0.928$ and RMSEA $=0.056$. The structural model has revealed that the relationship between personal qualities, business competences, and environmental factors are moderated by training transfer in the study with measurement residual $X^{2}$ greater than unconstrained $X^{2}$ based on model comparison output $\Delta X^{2}(\mathrm{CMIN})=140.931 ; \Delta \mathrm{df}=57 ; p=0.000$. Therefore, there is presence of moderation effect of training transfer on the determinants of entrepreneurial performance in the overall model.
\end{abstract}

Keywords: Business Competences, Environmental Factors, Entrepreneurial Performance, Nigeria, Personal Qualities and Training Transfer.

JEL Classification: M53

\section{INTRODUCTION}

There are a number of factors that are important and influential in terms of the emergence, practice, training development and performance of the entrepreneurs, particularly among the owners of micro, small and medium enterprises (MSMEs) and the entrepreneurial businesses in general. Many studies have attested to the central importance of the environmental or contextual factors including family, cultural, socio-economic, political, psychological and technological acting independently or in combination to shape the performance of business owners (Genty et al., 2015; Hisrich, Peters \& Shepherd, 2008; Ibeh, 2004; Ogundele \& Opeifa, 2003).

In Nigeria, and Lagos State in particular despite the significance and contribution of micro, small and medium enterprises to the national economy, many problems and constraints still exist in promoting their development and growth, which invariably affect the performance of the owners. This, in turn, has led to the 
dwindling in the number of MSMEs in Nigeria (Genty \& Idris, 2014). The decline is attributed to poor personal traits of entrepreneurs in Nigeria, under-developed human resources, and the harsh operating business environment (Adebisi \& Oni, 2012; Eneh, 2010). In addition, MSME failures particularly in emerging economies have been attributed to a lack of preparedness as a result of inaccurate entrepreneurial training transfer and lack of basic education on entrepreneurial skills (Genty, Idris, \& Pihie, 2014).

However, no particular literature at the time of conducting this study observed the moderating influence or effect of training and development transfer on the determinants of entrepreneurial performance. Therefore, this study takes up the responsibility of establishing the moderating effect of training transfer on the relationship between business competences, environmental factors, and personal qualities of MSME owners on their performance in Nigeria.

\section{LITERATURE REVIEW}

\subsection{Determinants of Entrepreneurial Performance}

Several theories which can be described as psychological, sociological, cultural, economic, political and historical have been developed to explain the path of emergence, behaviours and performance of the entrepreneur, as well as the impact of environmental influences on the process of entrepreneurship. The environment as operationally defined refers to the external and internal factors that affect the emergence of individual MSME business owners and entrepreneurial organisational activities in terms of vision, mission, strategies, decision system, performance and competitiveness. The psychological theory emphasises the personality traits such as the need for achievement, power, desire for accomplishment, personal locus of control, flexibility, thriftiness, risk taking and ability to perceive opportunities and threats (Teoh \& Chong, 2007; Drucker, 1985; Miron \& McClelland, 1979).

The socio-cultural theory sees entrepreneurship as a role and its development as a function of forming society and characteristics with culture. Such cultural environments have aided entrepreneurship by providing for business ideas, valuable information, resources, opportunities, social relations network and other supports that directly and positively influence the process rather than emergence, behaviours and performance of the entrepreneurship. For the economic theory, entrepreneurship is referred to the man who perceives business opportunities and takes advantage of scare resources and the structure of economic incentives available in the market, which have influence on the emergence, behaviours and performance of the entrepreneur (Schumpeter, 1943, Drucker 1985). The historical theory considers the past historical events as independent variables on emergence and performance of the entrepreneurship (Akeredolu-Ale, 1975; Hisrich, Peters \& Shepherd, 2008).

The development theory deals with occupational choice and development of entrepreneurial skills, which include training designs and transfer of skills and competences in opportunity awareness of relevant public, technology, market and 
dealing with government agencies at the micro level. Here, attitudinal and behaviour changes, motivation, education, human capital development and work experience and orientation act as determinants of effective entrepreneurship (Akeredolu-Ale, 1975; Hisrich, Peters \& Shepherd, 2008). The experiential theory emphasises the varied exposure of the individual in a social, occupational and other environment that enables the entrepreneur to acquire skills and knowledge necessary for running the organisation successfully (Kew, 2015; Ibeh, 2003; Kilby, 1971; Unger, 2006). In the same vein, the managerial theory focuses on the perception of market opportunities, managerial and operation skills, strategic management practices, all with direct positive influence on the part of the entrepreneurship process (Genty \& Idris, 2014; Kilby, 1971; Osuagwu, 2001). The innovation theory considers the development of new products, services and ideas, thus giving enterprises forms of producing capacity (Schumpeter, 1943; Drucker, 1985, Kilby, 1971).

\subsection{Model of Entrepreneurial Process for Personality Skills and Development}

The model of the entrepreneurial process focuses on developing relevant personal traits and skills in the entrepreneurs or business owners. There are five broad categories of such personal level skills shown in Fig. 1. The relevant issues are activities, skills, drivers, ten sets of Ds, and the evolution of the individuals. Each of these five categories has several elements, which if property developed and transferred in the entrepreneurs and business owners will make them effective achievers. The evolution process clearly brings out the relevance of the environment that can be simulated in training and the development of the entrepreneurial personality. In essence, the activities, skills, drivers, personal status are all affected by the transfer of training and acquisition of skills and competences undertaken in similar entrepreneurial environment.

Sánchez (2013) refers to entrepreneurial training as entrepreneurship programmes that focus on the teaching of basic entrepreneurial skills, practice, business plan and the interaction of these components with practitioners in order to improve competences and intentions of becoming business owners. Therefore, entrepreneurs and business owners are agents of economic, social and technological changes in society. They are business leaders who are concerned with exploiting business opportunity for profit and economic development. A nation that values human capital development should establish and organise training and development programmes that will churn out a large number of entrepreneurs. They should be equipped with relevant and adequate attributes, skills and competences for initiating and managing their businesses efficiently and effectively.

Training is concerned with the appropriate design implementation, acquisition and transfer of skills, specific knowledge, attitudinal changes, techniques for competences and business process as well as development experiences, which are required to perform particular jobs, production or services (Idris et al., 2013; Nwanaka \& Amaehule, 2011). Thus, it involves a systematic process of training and growth, through which the individuals and business owners gain, apply and effectively transfer skills. Knowledge insight and attitude to manage work 
structures and business enterprises effectively with consequential effects on business and national economic growth are related to development (Genty et al., 2015).

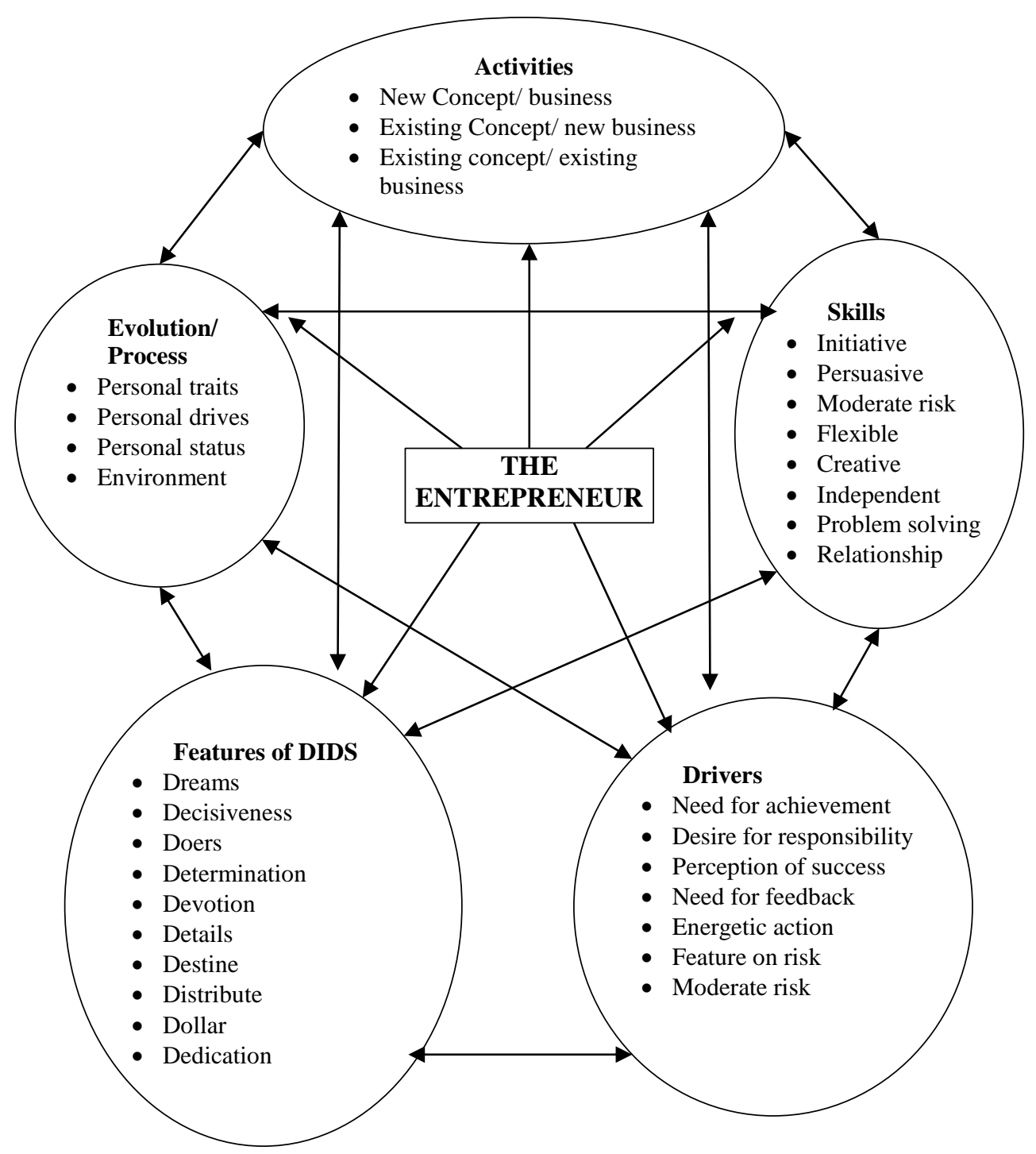

Fig. 1. Entrepreneurship and environment (Ogundele \& Opeifa, 2003).

Ladzani \& van Vuuren (2002) argued that an organisation irrespective of its size needs training for its employees in order to comply with the rapid changing circumstances, especially in small business. It could help owners/managers of small businesses to learn how to approach certain problems, save time and money as well as become aware of certain rules and procedures to overcome difficulties. The scholars posit that useful training might include motivational, business, and entrepreneurial skills training but point out that a majority of the training institutions only conduct training in one area without necessarily looking at the transfer of the training. 


\subsection{Transfer of Training}

Transfer of training has been defined as the effective and unending application of the knowledge and skills gained by the trainee during and after training to their jobs. There are two facets to the transfer of training. The first is application that is the trainees immediately apply all that they have learnt in training to their jobs, while the second is the practice that is with practice on the job, the trainees' level of skills will increase. Initial research on the transfer of learning was steered by theories that accentuated the likeness between conditions of learning and conditions of transfer.

Training transfer is grounded on three major adult learning theories, namely self-directed, situated cognition, and transformational learning (Toll, 2004). These three theories of adult education gave the basic principles and practices that need to be followed to enhance learning transfer efforts. Adult learning theories are typically addressing the learner, the context, and the learning process (Chen, 2003; Toll, 2004; Zhang, 2012). Self-directed learning theory supports the importance of individual learner's characteristics whereby the learner's autonomy, motivation, attitudes and experience are acknowledged. Self-directed learning is characterised with learner-centred training programme design where learners acquire knowledge, skills and attitudes by doing themselves. It allows for autonomous learning through introvert and extrovert mechanisms as well as recognising the importance of the socio-cultural or organisational context of learning (Huang, 2010).

Transfer of training has also been categorized in terms of 'near transfer' and 'far transfer'. Near transfer of skills and knowledge refers to the replication of the earlier assimilated knowledge and skills in all identical circumstances based on Thorndike's theory of 'identical elements', while 'far transfer' is otherwise. One of the foremost glitch organisations are faced with today is the failure of employees transferring the training they have acquired to their workplace. In this study, however, there is scanty research on training transfer in the context of entrepreneurship studies. Surprisingly, no empirical study has been able to systematically investigate the moderating effect of training transfer on the relationship between the determinants and entrepreneurial performance in the Nigerian context. Thus, this study hypothesises that:

$H_{o}$ : Training transfer moderates the relationship between personal qualities, business competences, and environmental factors on entrepreneurial performance among the owners of manufacturing micro, small and medium enterprises in Lagos State, Nigeria.

\subsection{Theoretical Framework}

From the resource-based view of strategic management perspective, it is evident that firm-specific factors such as human capital are important in determining firm performance (Iakovleva, 2002). However, there are mixed results of firm performance at the individual, organisational, and environmental level of analysis. Thus, using the constructs such as personal qualities, business competences, and environmental munificence factors in determining 
entrepreneurial performance might be inconclusive or rather yield mixed findings. Therefore, the key to every entrepreneurial performance is supposed to come from human resource and entrepreneurs themselves (Rosli \& Mahmood, 2013). This is because human resources provide a rare and incomparable source of competitive advantage and firm performance than other resource-based views (Busenitz \& Barney, 1997). Similarly, human beings are at the centre stage of any organisation to achieve its goals and objectives, irrespective of the firm size, structure, strategies and other organisational level of analysis adopted.

Therefore, the significance of training cannot be underestimated in entrepreneurial performance debate. In today's knowledge-economy, creativity and capacity of entrepreneurs enable them to compete favourably. Thus, creativity and capability can be acquired and improved through education, training and experience, which can eventually lead to firm performance. The lack of training transfer has been attributed to trainees' characteristics, training design and delivery, and work environment influences (Baldwin \& Ford, 1988). Therefore, there is a serious need for human resource development researchers and practitioners to focus on designing intervention programmes that will support individual, team and organisational performance as a core issue of HRD (Burke \& Hutchins, 2007).

\section{METHODOLOGY}

In this study, descriptive survey research design has been adopted to elicit data among the owners of 1.195 registered existing micro, small and medium enterprises in Lagos State, Nigeria (MSME Survey, 2012). In the study, as the population of MSME owners is known, Cochran (1977) formulae has been used, which estimated the sample size to 437 MSMEs. This figure has been proportionately distributed among five divisions in Lagos State, namely Ikeja, Badagry, Ikorodu, Lagos Island and Epe.

A multistage cluster sampling techniques have been employed to draw a representative sample size. The method is the combination of stratified and cluster sampling techniques, as well as the involvement of simple random. The researchers ensure that the participants are the founders or CEOs of MSMEs in order to elicit first-hand information. Five instruments have been adopted and used in the study to measure the constructs under consideration. An instrument developed by $\mathrm{Chu}$, Kara and Benzing (2008) has been used to measure entrepreneurial performance, while a modified scale of Entrepreneurial Attitude and Orientations (EAO) design by Robinson et al. (1991) has been used to measure personal qualities. Similarly, Maharati \& Nazemi (2012) instrument on competences has been adopted and used to measure business competences in the study, meanwhile a modified version of environmental munificence factor developed by Tang (2008) has been adapted to measure environmental factors. Finally, the moderator which is 'training transfer' has been measured using the adapted scale of Learning Transfer System Inventory (LTSI) developed by Holton III, Bates and Ruona (2000).

All the instruments are in 5-point Likert scale ranging from strongly disagrees to strongly agree. The Cronbach Alpha reliability of the instruments is above cutoff point 0.7 . The questionnaires have been sent to the respondents for a period of 
four months. Three hundred and fifty questionnaires have been completed, of which 307 are considered valid and usable for the analysis representing $70.3 \%$. The collected demographic data have been analysed descriptively with SPSS version 22.0, while the stated research hypothesis has been tested inferentially with the aid of Structural Equation Modelling (SEM). The next section discusses the data analysis in detail.

\section{ANALYSIS AND RESULT}

\subsection{Test for Presence of Moderation}

A moderator is a variable that alters the strength of the causal relationship between independent and dependent variable (Baron \& Kenny, 1986). In structural equation modelling (SEM), the test of a moderator is done through Multi-Group Analysis whereby data are split into groups based on the moderator. In this study, the moderator is 'training transfer', which involves splitting the data into group of entrepreneurs that have 'low level training transfer' and group with 'high level training transfer'. According to Hair et al. (2010), Multi-Group Analysis can test moderation effects of the moderator in two different ways, namely, the overall model and the individual paths.

The overall model is the first step to test the moderation effect on the structural model, that is, to establish that there is presence of moderation effect of the moderator variable on the overall model. Testing of the moderation effect on the individual paths, on the other hand, involves the establishment of moderator on individual paths. However, six (6) models are created during the establishment of moderation effects, namely, unconstrained, measurement weight, structural weight, structural covariance, structural residuals, and measurement residuals. This study, however, adopts Hair et al. (2010) criteria to analyse the moderating effect of training transfer on the determinants of entrepreneurial performance, namely, personal qualities, business competences, and environmental munificence factors.

\subsection{Testing of Research Hypothesis}

Figure 2 below illustrates the fit indices of the structural model for testing the moderation effects of training transfer on the determinants of entrepreneurial performance. Based on the recommendation of Hair et al. (2010) that if any 3 or 4 of the goodness-of-fit indices are within the threshold then the entire model is fit and the model is acceptable for further analysis because the data fit the study structural model. The relative chi-squares for both measurement residual and unconstrained models are less than 5.0, the CFIs and the TLIs are greater than 0.9 while the RMSEAs are less or equal to 0.08. Thus, the structural models meet more than four (4) goodness-of-fit indices as recommended by Hair et al. (2010). 


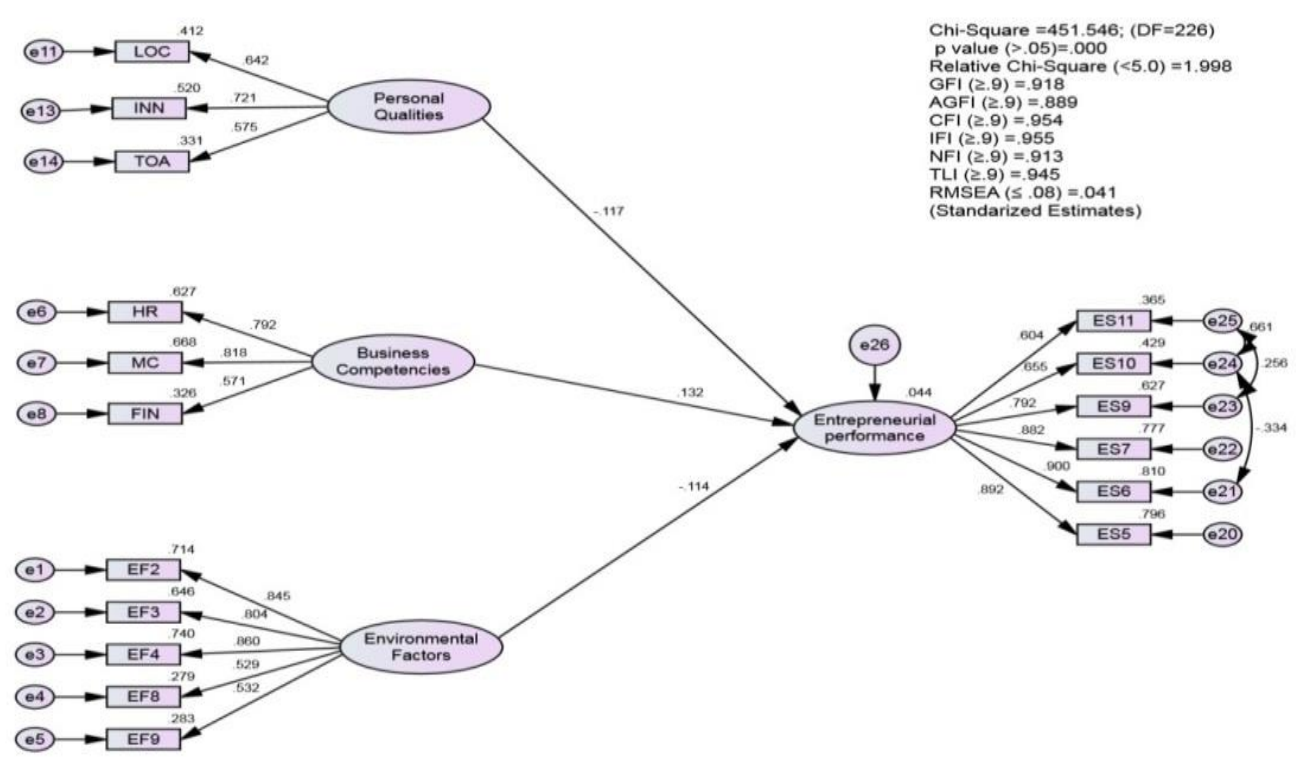

Fig. 2. The overall structural path model for group 1 (high level training transfer)

Note: $\mathrm{LOC}=$ Locus of control; INN= Innovativeness; TOA= Tolerance of ambiguity; HR= Human resource competency; $\mathrm{MC}=$ Marketing competency; FIN= Financial management competency; $\mathrm{EF}=$ Environmental munificence factors; $\mathrm{TOT}=$ Training transfer; and $\mathrm{ES}=$ Entrepreneurial performance.

Table 1 below indicates that the measurement residual $X^{2}$ is greater than unconstrained $X^{2}$ based on $\Delta X^{2}(\mathrm{CMIN})=10.925 ; \Delta \mathrm{df}=40 ; p=0.000$ but the unconstrained model has been found to be better than the measurement residual model because of other indices.

Table 1: The Moderation Test Result using Training Transfer Group Data

\begin{tabular}{|l|r|r|r|r|r|}
\hline \multicolumn{1}{|c|}{ Indices } & $\begin{array}{c}\text { Measurem } \\
\text { ent } \\
\text { residuals }\end{array}$ & $\begin{array}{c}\text { Unconstrained } \\
\text { model }\end{array}$ & $\begin{array}{c}\text { Chi- } \\
\text { square } \\
\text { difference }\end{array}$ & $\begin{array}{c}\text { Result on } \\
\text { moderation }\end{array}$ & $\begin{array}{c}\text { Hypothesis } \\
\text { result }\end{array}$ \\
\hline Chi-square $\left(X^{2}\right)$ & 462.471 & 451.546 & $\mathbf{1 0 . 9 2 5}$ & Significant & $\begin{array}{c}\text { Not } \\
\text { supported }\end{array}$ \\
\hline$p$ values & 0.000 & 0.000 & & & \\
\hline DF & 266 & 226 & $\mathbf{4 0}$ & & \\
\hline GFI & 0.916 & 0.918 & & & \\
\hline CFI & 0.960 & 0.954 & & & \\
\hline TLI & 0.959 & 0.945 & & & \\
\hline RMSEA & 0.035 & 0.041 & & & \\
\hline $\begin{array}{l}\text { Relative } \\
\text { chi-square } \\
\text { (CMIN/DF) }\end{array}$ & 1.739 & 1.998 & & & \\
\hline $\begin{array}{l}\text { Ho }: \text { Training transfer does not moderate the relationship between personal } \\
\text { qualities, business competences and environmental factors on entrepreneurial } \\
\text { performance among the owners of manufacturing micro, small and medium }\end{array}$ & \\
enterprises in Lagos State, Nigeria. & \\
\hline
\end{tabular}


Therefore, there is the presence of moderation effect of training transfer on the determinants of entrepreneurial performance in the overall model. Thus, the researchers should reject $\mathrm{H}_{0}$ which says: "Training transfer does not moderate the relationship between personal qualities, business competences and environmental munificence factors on entrepreneurial performance among the owners of manufacturing micro, small and medium enterprises in Lagos State, Nigeria".

This implies that training transfer moderates the relationship between personal qualities, business competences and environmental factors on entrepreneurial performance among the owners of manufacturing micro, small and medium enterprises in Lagos State, Nigeria. Thus, once the moderation effect is established, the study aims at determining in which group (high level training transfer group or low level training transfer group) the moderating effect is more pronounced on the relationship between the determinant variables and entrepreneurial performance.

\subsection{Testing the Moderating Effect of Training Transfer on the Determinants of Entrepreneurial Performance}

The relationship between personal qualities and entrepreneurial performance when moderated by training transfer reveals that the entrepreneurs that have 'high level training transfer' $(\beta=-0.117, p=0.099)$, while entrepreneurs who have 'low level training transfer' $(\beta=-0.073, p=0.318)$. The group with high level training transfer is non-significant at 0.05 level of significance, at the same time the group with low level training transfer is also insignificant. Therefore, there is absence of moderation in the relationship between personal qualities and entrepreneurial performance. This violates Hair et al. (2010) decision criteria. The researcher concludes that training transfer does not moderate the relationship between personal qualities and entrepreneurial performance among the owners of manufacturing MSMEs in Lagos State, Nigeria.

Table 2. Results of Moderation Test of Training Transfer on the Relationship between the Determinants and Entrepreneurial Performance

\begin{tabular}{|l|r|r|r|}
\hline \multicolumn{1}{|c|}{ Constructs } & B & $\boldsymbol{1}$ & \multicolumn{1}{c|}{$\boldsymbol{\beta}$} \\
\hline Personal Qualities & -0.171 & -0.117 & 0.099 \\
\hline High Training Transfer & -0.091 & -0.073 & 0.318 \\
\hline Low Training Transfer & 0.177 & 0.132 & 0.045 \\
\hline Business Competences & -0.151 & -0.135 & 0.049 \\
\hline High Training Transfer & -0.094 & -0.114 & 0.068 \\
\hline Low Training Transfer & 0.018 & 0.026 & 0.690 \\
\hline Environmental Factors & \multicolumn{5}{|l}{} \\
\hline High Training Transfer & Low Training Transfer &
\end{tabular}

The relationship between business competences and entrepreneurial performance has been examined with moderated effect of training transfer in this study. Entrepreneurs that have higher level training transfer reveal $(\beta=0.132$, $p=0.045)$ while entrepreneurs that have low level of training transfer show $(\beta=-0.135, p=0.049)$. According to Hair et al. (2010) rule, the beta $(\beta)$ for both 
groups is significant but the group with high level training transfer is positive while the group with low level training transfer is negative. Therefore, the study concludes that the relationship between business competences and entrepreneurial performance is moderated by training transfer.

Finally, the structural model shows that the standardized coefficient of environmental munificence factors on entrepreneurial performance is not moderated by training transfer. An indication that training transfer does not moderate the relationship between environmental munificence factor and entrepreneurial performance. Therefore, the relationship between environmental munificence factors and entrepreneurial performance as illustrated in Table 2 depicts that entrepreneurs with high level training transfer have $\beta=-0.114$, $p=0.068)$ while entrepreneurs who have low level training transfer have $(\beta=0.026$, $p=0.690)$. In both groups Beta $(\beta)$ values are negative and positive respectively, but the significant levels of the groups meet Hair et al. (2010) rule; therefore, training transfer does not act as a moderator in this relationship.

\section{CONCLUSION}

In this study, the moderating role of training transfer has been examined on entrepreneurial performance determinants such as personal qualities, business competences, and environmental munificence factors. Though, the moderating effect of the training transfer on the relationship between personal qualities, business competences, and environmental munificence factors has not been established before, particularly in developing economies such as Nigeria. This finding found support in the work of Nikandrou, Brinia, \& Bereri (2009) on trainee perception of training transfer: an empirical analysis. This was attributed to the fact that personal qualities are psychological traits, which have to do with feelings and perceptions of individual entrepreneurs that are very difficult to imitate and acquire according to these scholars because individual personality traits are inherent.

The relationship between business competences and entrepreneurial performance has also been examined in this study with moderation effect of training transfer. The study reveals that training transfer moderates the relationship between business competences and entrepreneurial performance. The findings of the present study support the work of Yusuf (1995) on the critical success factors for small business success among South Pacific entrepreneurs. The scholar found out that good management skills or competences were significant to small business success among South Pacific entrepreneurs. This was attributed to availability of management experience and managerial talent among the indigenous and nonindigenous entrepreneurs in South Pacific based on training, which in turn was transfer to the SMEs.

Concerning environmental munificence factors and entrepreneurial performance, the moderating effect of training transfer is non-significant. This is an indication that there is no moderation of training transfer on the relationship between environmental munificence factors and entrepreneurial performance. Surprisingly, many studies on entrepreneurial performance relationship using the environment as a moderator have found significant effects of environmental 
munificence factors on entrepreneurial performance (Erofeev, 2002; Tang, 2008; Yaghoob, Rose, \& Kumar, 2010). This has not been found in the present study.

\section{REFERENCES}

Adebisi, T.A., \& Oni, C.S. (2012). Assessment of Relevance of the National Directorate of Employment (NDE) Training Programmes to the Needs of the Trainees in Southwestern Nigeria. International Journal of Vocational and Technical Education, 4(3), 29-37. Retrieved from http://www.academicjournals.org/app/webroot/article/article1379424493_Adebisi\%20and\%20Oni.pdf

Akeredolu-Ale, E. (1975). Underdevelopment of Indigenous Entrepreneurship in Nigeria. Ibadan University Press.

Baldwin, T.T., \& Ford, J. K. (1988). Transfer of Training: A Review and Directions for Future Research. Personnel Psychology, 41(1), 63-105. https://doi.org/10.1111/j.1744-6570.1988.tb00632.x

Baron, R.M., \& Kenny, D.A. (1986). The Moderator-Mediator Variable Distinction in Social Psychological Research: Conceptual, Strategic, and Statistical Considerations. Journal of Personality and Social Psychology, 51(6), 1173-1182. http://dx.doi.org/10.1037/0022-3514.51.6.1173

Burke, L. A., \& Hutchins, H.M. (2007). Training Transfer: An Integrative Literature Review. Human Resource Development Review, 6(3), 263-296. https://doi.org/10.1177/1534484307303035

Busenitz, L., \& Barney, J. (1997). Differences Between Entrepreneurs and Managers in Large Organizations: Biases and Heuristics in Strategic Decision-Making. Journal of Business Venturing, 12(1), 9-30. https://doi.org/10.1016/S0883-9026(96)00003-1

Chen, H.C. (2003). Cross-Cultural Construct Validation of the Learning Transfer System Inventory in Taiwan. LSU Doctoral Dissertations. 2254. Retrieved from https://digitalcommons.lsu.edu/cgi/viewcontent.cgi?referer=https://www.google.com/\&httpsredir=1\&arti cle $=3253 \&$ context $=$ gradschool_dissertations

Chu, H.M., Kara, O., \& Benzing, C.D. (2008). An Empirical Study of Nigerian Entrepreneurs: Success, Motivations, Problems, and Stress. International Journal of Business Research, 8(2), 102-116. Retrieved from https://goo.gl/HUhQJT

Cochran, W. G. (1977). Sampling Techniques (3rd ed.). New York: John Wiley and Sons.

Drucker, P.F. (1985). Innovation and Entrepreneurship: Practice and Principle. New York: Harper \& Row.

Eneh, O. (2010). Survival Strategies for Entrepreneurs in Dwindling Nigerian Economy. Asian Journal of Industrial Engineering, 2(2), 52-62. https://doi.org/10.3923/ajie.2010.52.62

Erofeev, D. (2002). Personal, Organisational, and Environmental Factors as Predictors of Entrepreneurial Success within a Franchising Company in the Personnel Service Industry. PhD thesis, Department of Psychology, Central Michigan University. United States, Michigan.

Hair, J., Black, W., Babin, B., \& Anderson, R. (2010). Multivariate Data Analysis (7th Ed.). Pearson Prentice Hall.

Hisrich, R.D., Peters, M.P., \& Shepherd, D.A. (2008). Entrepreneurship ( $9^{\text {th }}$ ed.). New York, NY, USA: McGraw-Hill.

Holton III, E. F., Bates, R.A., \& Ruona, W.E.A. (2000). Development of a Generalized Learning Transfer System Inventory. Human Resource Development Quarterly, 11(4), 333-360. https://doi.org/10.1002/1532-1096(200024)11:4<333::AID-HRDQ2>3.0.CO;2-P

Huang, Z.J. (2010). Penrose's Enterprise Growth Theory on China's Enterprise Development. International Conference on Management and Service Science, 1-3. https://doi.org/10.1109/ICMSS.2010.5575338

Iakovleva, T. (2002). Theorizing on Entrepreneurial Performance. 1-42. Retrieved from https://goo.gl/Bovg2R

Ibeh, K.I.N. (2003). Toward a Contingency Framework of Export Entrepreneurship : Conceptualisations and Empirical Evidence. Small Business Economics, 20(1), 49-68. https://doi.org/10.1023/A:1020244404241

Ibeh, K.I.N. (2004). Furthering Export Participation in Less Performing Developing Countries: The Effects of Entrepreneurial Orientation and Managerial Capacity Factors. International Journal of Social Economics, 31(1/2), 94-110. https://doi.org/10.1108/03068290410515448

Idris, K., Shaffril, M., Silva, J.L.D., \& Man, N. (2013). Identifying Problems among Seabass Brackish-Water Cage Entrepreneurs in Malaysia. Asian Social Science, 9(9), 249-256. https://doi.org/10.5539/ass.v9n9p249

Genty, K.I., \& Idris, K. (2014). Entrepreneurial Training Model, a Predictor to Entrepreneurs' Success: The Contending Viewpoint. In Proceedings of the 2014 Global Business and Finance Research Conference, Melbourne, Australia, 5-6 May 2014.

Genty, K.I., Idris, K., Wahat, N.A., \& Kadir, S.A. (2015). Demographic Factors as a Predictor of Entrepreneurs' Success among Micro, Small and Medium Enterprises (MSMEs) Owners in Lagos State, Nigeria. IOSR Journal of Business and Management (IOSR-JBM), 17(11), 125-132. https://goo.gl/HE6kNp 
Genty, K.I., Idris, K., \& Pihie, Z.A.L. (2014). Exploring Entrepreneurship Education and Training Programme on Venture's Creation in Nigeria: A Study of SMEDAN Corper's Entrepreneurship Development Programme (CEDP). Elixir Management Arts, 72, 25710-25721. Retrieved from https://www.elixirpublishers.com/articles/1405943306_72\%20(2014)\%2025710-25721.pdf

Kew, J. (2015). Africa's Young Entrepreneurs: Unlocking the Potential for a Brighter Future. GEM, IDRC, CRDI, Canada. 1-72. Retrieved from https://www.idrc.ca/sites/default/files/sp/Documents\%20EN/Africas-Young-Entrepreneurs-Unlockingthe-Potential-for-a-Brighter-Future.pdf

Kilby, P. (1971). The Heffalump Revisited. Journal of International Entrepreneurship, 1(1), 13-29. https://doi.org/10.1023/A:1023282115703

Ladzani, W. M., \& van Vuuren, J. J. (2002). Entrepreneurship Training for Emerging SMEs in South Africa.

Journal of Small Business Management, 40(2), 154-161. https://doi.org/10.1111/1540-627X.00047

Maharati, Y., \& Nazemi, S. (2012). Entrepreneurial Drives, Organizational Function, and Success of Iranian Entrepreneurs. Advances in Management \& Applied Economics, 2(2), 147-177. Retrieved from http://www.scienpress.com/Upload/AMAE\%2FVol\%202_2_7.pdf

Miron, D., \& McClelland, D.C. (1979). The Impact of Achievement Motivation Training of Small Businesses. California Management Review, 21(4), 13-28. https://doi.org/10.2307/41164830

MSME Survey (2012) Survey Report on the Micro, Small and Medium Enterprises in Nigeria. A Preliminary Report, 2010 National MSME Collaborative Survey. A Collaboration between National Bureau for Statistics (NBS) and the Small and Medium Enterprises Agency of Nigeria (SMEDAN). Retrieved from http://www.smedan.gov.ng/doc

Nikandrou, I., Brinia, V., \& Bereri, E. (2009). Trainee Perceptions of Training Transfer: an Empirical Analysis. Journal of European Industrial Training, 33(3), 255-270. https://doi.org/10.1108/03090590910950604

Nwanaka, C.R., \& Amaehule, S. (2011). Skills Acquisition: Imperative for Business Studies Educators Among Secondary Schools In Rivers State. In Proceedings of the 2011 International Conference on Teaching, Learning and Change, 653-661. Retrieved from http://hrmars.com/admin/pics/176.pdf

Ogundele, O., \& Opeifa, A. (2003). Factors that Influence the Emergence, Behaviour and Performance of Entrepreneurs in Nigeria. The Abuja Management Review: AMR: Journal of the Faculty of Management Sciences, University of Abuja, 1(2), 1-19.

Osuagwu, L. (2001) Small Business Entrepreneurship Management. 1st Edition, Grey Resources Limited, Lagos.

Robinson, P., Stimpson, D., Huefner, J., \& Hunt, H. (1991). An Attitude Approach to the Prediction of Entrepreneurship. Entrepreneurship Theory and practice, 15(4), 13-32. https://doi.org/10.1177/104225879101500405

Rosli, M.M., \& Mahmood, R. (2013). Moderating Effects of Human Resource Management Practices and Entrepreneur Training on Innovation and Small-Medium Firm Performance. Journal of Management \& Strategy, 4(2), 60-69. https://doi.org/10.5430/jms.v4n2p60

Sánchez, J.C. (2013). The Impact of an Entrepreneurship Education Program on Entrepreneurial Competencies and Intention. Journal of Small Business Management, 51(3), 447-465. https://doi.org/10.1111/jsbm.12025

Schumpeter, J.A. (1943). Capitalism, Socialism, and Democracy (6th ed.). London and New York: George Allen \& Unwin.

Tang, J. (2008). Environmental Munificence for Entrepreneurs: Entrepreneurial Alertness and Commitment. International Journal of Entrepreneurial Behavior \& Research, 14(3), 128-151. https://doi.org/10.1108/13552550810874664

Teoh, W.M., \& Chong, S.H. (2007). Theorising a Framework of Factors Influencing Performance of Women Entrepreneurs in Malaysia. Journal of Asia Entrepreneurship and Sustainability, III(2). Retrieved from http://www.asiaentrepreneurshipjournal.com/AJESIII2Teoh.pdf

Toll, D. (2004). The Transfer of Learning: Employees' Lived Experience. University of Ottawa, Canada.

Unger, J.M. (2006). Entrepreneurial Success: The role of Human Capital and Learning. Retrieved from https://core.ac.uk/download/pdf/56343208.pdf

Yaghoob, M., Rose, R., Kumar, N., \& Nazemi, S. (2010). The Moderating Role of National Culture on the Relationship between Personal Qualities of Entrepreneurs and their Success in Small Industries in Iran. International Conference on Business and Economic Research-ICBER2010, November 26-28, 2010, Kuala Lumpur, 1-23.

Yusuf, A. (1995). Critical Success Factors for Small Business : Perceptions of South Pacific Entrepreneurs. Journal of Small Business Management, 33(2), 68-74.

Zhang, X. (2012). The Impact of Entrepreneurial Learning on Entrepreneurial Performance: The Mediating Role of Entrepreneurial Competencies. In: Xie A., Huang X. (eds) Advances in Electrical Engineering and Automation. Advances in Intelligent and Soft Computing, 139, 229-234. https://doi.org/10.1007/978-3-642$\underline{27951-5 \_34}$ 


\section{AUTHOR'S SHORT BIOGRAPHY}

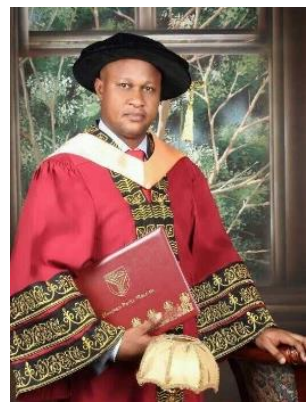

Kabiru Ishola Genty was born on 15th April 1980 in Epe Local Government Area of Lagos State, Nigeria. He started his elementary school at Community Primary School, Erepoto Epe from 1985 to 1990 . He attended Ogunmodede College, Papa Epe from 1990 to 1996. After that, he proceeded to Lofi-Ogunmude Comprehensive College, Ejinrin-Ketu, Epe, for his West African Senior Secondary School Certificate Examination (WASSCE) in the year 1999.

Dr. Genty later proceeded to Lagos State Polytechnic for his National Diploma (ND) in Town \& Regional Planning from 1999 to the year 2001. He obtained his B.sc (Hon) and M.sc degrees in Industrial Relations and Human Resource Management in 2005 and 2009 respectively from Lagos State University, Ojo Lagos, Nigeria. In the year 2012, he continued studies at the University of Kassel and Berlin School of Economic \& Law, Germany for his M.A. degree in Labour Policies and Globalization.

Dr. Kabiru Genty obtained his Ph.D. in Human Resource Development from the University Putra Malaysia in the year 2016 and currently is a Lecturer at the Department of Industrial Relations \& Personnel Management, Lagos State University, Nigeria.

E-mail: ishola.genty@lasu.edu.ng

ORCID iD: https://orcid.org/0000-0002-7981-5688 